\title{
Detection and titration of white spot syndrome virus using a Blue-Cell ELISA
}

\author{
H H Shih \\ Department of Zoology, National Taiwan University, Taipei, Taiwan
}

Keywords: Blue-Cell ELISA, detection, titration, penaeids, white spot syndrome virus.

White spot syndrome virus (WSSV) is the causative agent of a shrimp disease which affects most of the commercially cultivated marine shrimp species globally and has become the leading cause of production losses (Flegel 1997). To monitor the progression of this disease in infected animals, the number of viral genomes has been determined by a competitive polymerase chain reaction (PCR) (Tang \& Lightner 2000), and the concentration of viral proteins has been measured using a capture enzyme-linked immunosorbent assay (ELISA) (Chen, Wang \& Shih 2002). However, study and quantification of WSSV is still hampered by the lack of a continuous cell culture system for shrimp.

The successful development of primary cell cultures has proven useful for studying WSSV and other shrimp viruses in vitro. The infectivity of the monodon-type baculovirus (MBV) in primary cultures prepared from the lymphoid organs of Penaeus monodon was initially reported by Chen $\&$ Kou (1989). A similar primary culture was also used for the quantal assay and evaluation of viral inhibitor for the non-occluded Chinese baculo-like virus (CBV) (Tapay, Lu, Gose, Nadala, Brock \& Loh 1997), now called WSSV. Kasornchandra \& Boonyaratpalin (1998) used primary shrimp cell cultures for propagation of WSSV, for determining WSSV tissue and organ specificity in $P$. monodon, and for determining the relative virulence of WSSV

Correspondence Dr H H Shih, Department of Zoology, National Taiwan University, Taipei 106, Taiwan (e-mail:shihhh@ccms.ntu.edu.tw) to various species of crustaceans. Recently, primary cell cultures from the lymphoid (Oka) organ of $P$. monodon were used to investigate in vitro propagation and morphogenesis of WSSV (Wang, Yang, Tang, Liu, Kou \& Lo 2000). In the absence of a WSSV-susceptible continuous shrimp cell line, primary cell cultures of shrimp tissues, and especially the lymphoid organ, are practical and powerful substitutes to study WSSV in vitro.

For isolation and typing of polioviruses, a simple and rapid procedure has been described for a microtitre plate method using a Blue-Cell ELISA (Samuel, Megson, Strang \& Appleton 2000). Test samples were inoculated onto monolayers of permissible cells grown in microwells. After 24$48 \mathrm{~h}$ incubation, regardless of whether cytopathic effects (CPE) had developed, the inoculated wells were stained for the presence of polioviruses using specific monoclonal antibodies (MAb) and antimouse horseradish peroxidase (HRP) conjugate. Infected cells stained an intense blue colour and were easily distinguished from hyaline uninfected cells. A similar protocol has been successfully used for immunochemical staining of WSSV in infected shrimp tissue sections using a MAb recognizing an epitope on the viral structural protein VP28 (Shih, Wang, Tan \& Chen 2001). In this study, primary cultures of the lymphoid organ were combined with a Blue-Cell ELISA to detect the presence and titrate the infectious dose of WSSV in infected shrimp samples.

Lymphoid Oka organs from $P$. monodon were harvested, pooled and processed for primary cell culture according to procedures described previously (Chen, Chi, Kou \& Liao 1986). The explant cultures 
were prepared in 48-well culture plates (Nunc, Roskilde, Denmark) and grown in $2 \times$ Leibovitz's L15 medium (L15) (Gibco-BRL, New York, USA) supplemented with $20 \%$ foetal bovine serum (FBS), $100 \mathrm{IU} \mathrm{mL}^{-1}$ penicillin, $100 \mu \mathrm{g} \mathrm{mL}^{-1}$ streptomycin, $0.25 \mu \mathrm{g} \mathrm{mL}^{-1}$ amphotericin $\mathrm{B}$ and $10 \%$ shrimp muscle extract. The shrimp used were WSSV PCR-negative using a reported protocol (Wang, Tsai, Kou \& Chen 1997). The seeded plates were incubated at $28{ }^{\circ} \mathrm{C}$ for $24 \mathrm{~h}$ or longer, then inoculated with gill extracts prepared from shrimp at various times after WSSV injection.

Primary cultures were prepared from the Oka organs of three common shrimp species including P. monodon, P. japonicus and Metapenaeus ensis. The lymphoid cells migrated from the seeded tissue explants and became confluent at $24 \mathrm{~h}$ in $P$. monodon (Fig. 1a), but at more than $48 \mathrm{~h}$ in the other two shrimp species. Therefore, live adult $P$. monodon tested as WSSV PCR-negative were used in this study. Two different cell types (fibroblast-like cells and squamous cells) were distinguished in the monolayer with the former being most abundant. Typical CPE on lymphoid cell monolayers were not apparent at $48 \mathrm{~h}$ post-inoculation with WSSV filtrate, although large vacuoles formed in some infected cells (Fig. 1b). Confluent monolayers still remained and they were used for the Blue-Cell ELISA protocol.

White spot syndrome virus used in this study was obtained from infected, farmed $P$. japonicus in Taiwan. A homogenate of the head soft tissues was
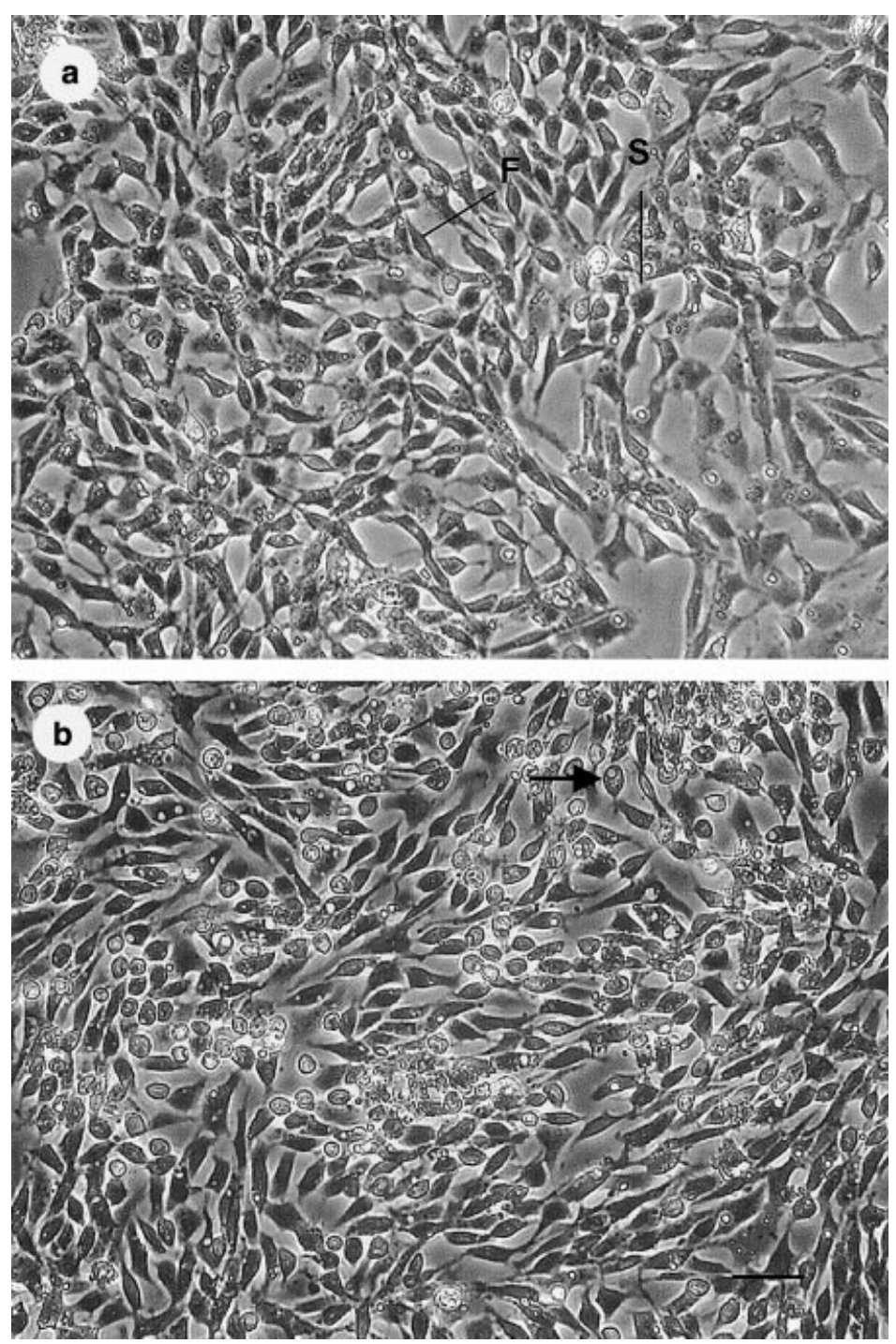

Figure 1 Phase contrast micrograph of primary cultures derived from lymphoid (Oka) organ of Penaeus monodon. (a) Uninfected cells $24 \mathrm{~h}$ after seeding, where two types of lymphoid cells can be seen: fibroblast-like cells (F) and squamous cells (S). (b) White spot syndrome virus (WSSV) infected lymphoid cells $48 \mathrm{~h}$ post-inoculation. Typical cytopathic effects are not apparent and the cell monolayer has not dislodged from the 48-well plate surface although large vacuoles (arrow) can be seen in some cells (bar $=30 \mu \mathrm{m}$ ). 
prepared in TNE buffer [50 mM Tris, $100 \mathrm{~mm}$ $\mathrm{NaCl}, 1 \mathrm{~mm}$ ethylene diamine tetraacetic acid (EDTA), $\mathrm{pH}$ 7.4] and centrifuged at $3000 \mathrm{~g}$ for $10 \mathrm{~min}$. The supernatant was filtered through a $0.45 \mu \mathrm{m}$ membrane filter, diluted with TNE buffer and then injected into abdominal muscle of healthy, WSSV PCR-negative $P$. vannamei (average weight: $10.5 \mathrm{~g}$ ) from a shrimp farm in north-eastern Taiwan. Branchial gill tissues were collected daily from individual shrimp. A $2 \%(\mathrm{w} / \mathrm{v})$ gill filtrate was prepared from each shrimp by grinding the tissues in TNE using a sterile mortar and pestle. The homogenate was centrifuged at $1500 \mathrm{~g}$ for $10 \mathrm{~min}$ and then filtered through a $0.22 \mu \mathrm{m}$ membrane filter.

For determination of virus titre in experimentally infected samples, 10-fold dilutions of WSSVcontaining filtrates were made in serum-free L15. For each dilution $\left(10^{-2}-10^{-9}\right), 0.1 \mathrm{~mL}$ was inoculated into each of six to eight wells of 24-h-old primary lymphoid cells. Virus adsorption was carried out for $1 \mathrm{~h}$ with gentle agitation at room temperature. At the end of the incubation, the excess filtrate was removed and $0.5 \mathrm{~mL}$ of maintenance medium (L15 containing 2\% FBS) was added into each of the wells. Control wells were only inoculated with maintenance medium as described above. The inoculated plates were incubated at $20^{\circ} \mathrm{C}$ for $48 \mathrm{~h}$, then processed for BlueCell ELISA for the determination of virus titre.

A combined protocol for Blue-Cell ELISA (Samuel et al. 2000) and immunochemical staining (Shih et al. 2001) was used in this study. Briefly, infected cells cultured in 48-well plates were fixed in cold acetone/PBS (80/20) for $10 \mathrm{~min}$ at $-20^{\circ} \mathrm{C}$ at $48 \mathrm{~h}$ post-inoculation. The acetone was aspirated and the wells air-dried. Endogenous peroxidase activity of cultured cells was blocked by adding $200 \mu \mathrm{L}_{\text {well }}{ }^{-1}$ blocking solution $\left(0.3 \% \mathrm{H}_{2} \mathrm{O}_{2} / 100 \%\right.$ methanol) for $30 \mathrm{~min}$. After rinsing in distilled water for $5 \mathrm{~min}$ and soaking in PBS for $10 \mathrm{~min}$, the cells were incubated with a serum block solution $(10 \%$ normal goat serum/PBS) for $20 \mathrm{~min}$ to minimize background reactions. Mouse ascites containing MAb 6E1, which recognized an epitope on the envelope protein VP28 of WSSV (Shih et al. 2001), was used as the primary antibody in this assay. It was diluted $1 / 1000$ in PBS containing $1 \%(\mathrm{w} / \mathrm{v})$ skim milk (PBS/SM) and $150 \mu \mathrm{L}$ was added to each well followed by incubation at $37{ }^{\circ} \mathrm{C}$ for $1 \mathrm{~h}$. The wells were washed three times with PBS and a 1/1000 dilution of antimouse immunoglobulin G (IgG) HRP conjugate (Kirkegaard \& Perry Laboratories, Inc., Gaithersburg, MD,
USA) in PBS/SM buffer was added to the wells and incubated at $37^{\circ} \mathrm{C}$ for $1 \mathrm{~h}$. Following washing three times in PBS, a TrueBlue peroxidase substrate (KPL) containing TMB and $\mathrm{H}_{2} \mathrm{O}_{2}$ was added for 5-10 min at room temperature until the infected cells were stained an intense blue/purple. After removing the substrate, the wells were rinsed in distilled water for $5 \mathrm{~min}$ and counter-stained with $0.2 \%$ aqueous neutral red for $1 \mathrm{~min}$. The cells were rinsed again with distilled water, observed and photographed using an inverted Olympus Microscope Model IX70 (Olympus Optical Co., Ltd., Tokyo, Japan). The number of positive wells, in which intense blue foci appeared, and negative wells were tabulated and used for computation of the TCID 50 by the method of Reed \& Muench (1938).

A preliminary time-course experiment processed the full test to define the positive reaction of the Blue-Cell ELISA. The results (not shown) revealed blue cells scattered in the monolayer as early as $12 \mathrm{~h}$ post-inoculation. In order to confirm the positive reaction, the Blue-Cell ELISA was carried out at $48 \mathrm{~h}$ post-inoculation. By that time the CPE had progressed and intense blue foci appeared as approximately $0.2-0.3 \mathrm{~mm}$ diameter spots that could be observed with the naked eye. Positive signals were seen primarily in the nuclei of culture cells (Fig. 2b) while WSSV-negative reaction was observed in uninfected controls (Fig. 2a).

The amount of infectious virus in the gills of experimentally infected $P$. vannamei was assayed by the Blue-Cell ELISA. After injection, shrimp became infected and the TCID $50 \mathrm{~mL}^{-1}$ titre was $10^{3.25}$ at $24 \mathrm{~h}$ post-injection (Table 1 ). Viral titre increased thereafter, reaching $10^{9.50}$ at 5 days postinjection, i.e. almost 2 million-fold higher than the titre at $24 \mathrm{~h}$ post-injection.

White spot syndrome virus from laboratory infected shrimp was detected and titrated by the

Table 1 Titration of white spot syndrome virus (WSSV) in gill filtrates of experimentally infected Penaeus vannamei using BlueCell ELISA

\begin{tabular}{ll}
\hline Sample $^{a}$ & WSSV titres \\
& \\
\hline 1-d PI & $\left(\log _{10} \mathrm{TCID}_{50} \mathrm{~mL}^{-1}\right)$ \\
2-d PI & $3.25 \pm 0.25$ \\
3-d PI & $4.67 \pm 0.33$ \\
4-d PI & $6.25 \pm 0.25$ \\
5-d PI & $7.67 \pm 0.33$ \\
\hline
\end{tabular}

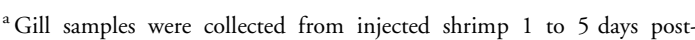
injection (PI).

${ }^{\mathrm{b}}$ Each titre is the mean and standard deviation of three samples. 


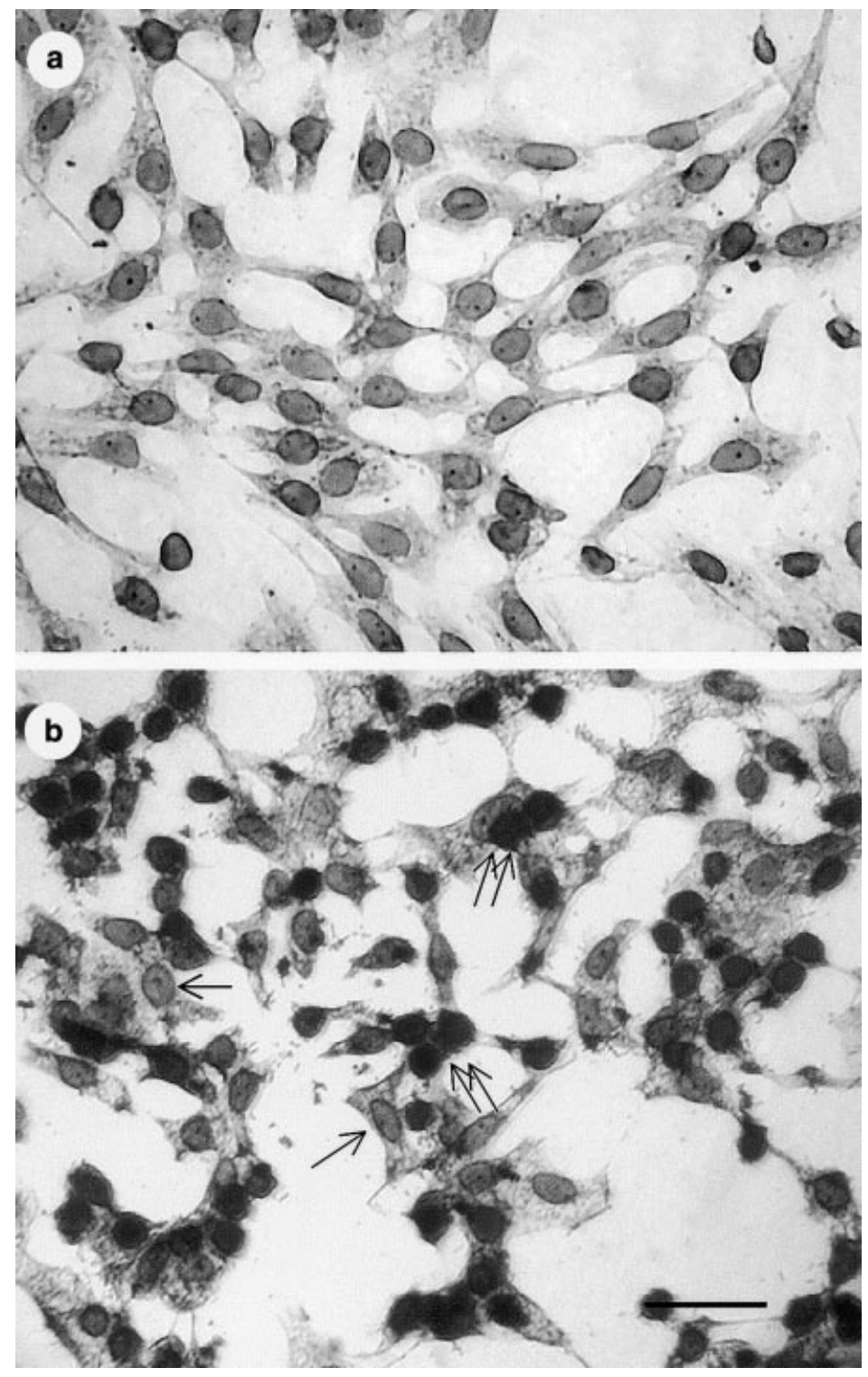

Figure 2 White spot syndrome virus (WSSV) detection in primary lymphoid cells by a Blue-Cell ELISA. (a) WSSV-negative reaction in uninfected cells. (b) WSSVpositive signals (double arrows) in cells at $48 \mathrm{~h}$ post-inoculation appearing as an intense blue colour primarily in nuclei. Some uninfected cells (arrows) show no reaction $(\mathrm{bar}=25 \mu \mathrm{m})$. end-point titration method (Reed \& Muench 1938) using primary lymphoid organ cell cultures combined with an immunostaining protocol. This quantification system was based on previous studies on primary culture of shrimp lymphoid organ tissues, on WSSV infectivity confirmation by in situ hybridization (ISH) (Wang et al. 2000) and in vitro propagation (Kasornchandra \& Boonyaratpalin 1998; Wang et al. 2000) and on an immunostainbased Blue-Cell ELISA applied for isolation and typing of poliovirus specimens (Samuel et al. 2000). In fact, an in vitro quantal assay for CBV has been developed using primary shrimp lymphoid cell cultures in 24-well tissue culture plates according to the appearance of CPE (Tapay et al. 1997).

Many methods of detecting WSSV have been reported. These include PCR (Wang et al. 1997), two-step PCR (Lo, Leu, Ho, Chen, Peng, Chen, Chou, Yeh, Huang, Chou, Wang \& Kou 1996), ISH (Wang, Tsai \& Chen 1998), Western blot (Nadala, Tapay, Cao \& Loh 1997), dot-blot nitrocellulose enzyme immunoassay (DB-NC-EIA) (Nadala \& Loh 2002), competitive ELISA (Hameed, Anilkumar, Raj \& Jayaraman 1998), and capture ELISA (Chen et al. 2002). This titration method could also be used for typing of geographic isolates, for 
studying potential antiviral therapy, for monitoring disease progress and for improving prevention and control of this important viral disease.

\section{Acknowledgements}

This work was supported by the Fisheries Administration, the Council of Agriculture, under Grant no. 90AS-1.4.5-FA-F3(11). I would like to thank L. F. Tan for the processing of primary cultures and Z. J. Chen for assistance in the experimental infection of shrimp.

\section{References}

Chen S.N. \& Kou G.H. (1989) Infection of cultured cells from the lymphoid organ of Penaeus monodon (Fabricius) by Monodon-type baculovirus (MBV). Journal of Fish Diseases 12, 73-76.

Chen S.N., Chi S.C., Kou G.H. \& Liao I.C. (1986) Cell culture from tissues of grass prawn, Penaeus monodon. Fish Pathology 24, 161-166

Chen Z.J., Wang C.S. \& Shih H.H. (2002) Quantal assay of white spot syndrome virus using a capture ELISA. Journal of Fish Diseases (in press).

Flegel T.W. (1997) Special topic review: major viral diseases of the black tiger prawn (Penaeus monodon) in Thailand. World Journal of Microbiology and Biotechnology 13, 433-442.

Hameed A.S.S., Anilkumar M., Raj M.L.S. \& Jayaraman K. (1998) Studies on the pathogenicity of systemic ectodermal and mesodermal baculovirus and its detection in shrimp by immunological methods. Aquaculture 160, 31-45.

Kasornchandra J. \& Boonyaratpalin S. (1998) Primary shrimp cell culture: application for studying white spot syndrome virus (WSSV). In: Advances in Shrimp Biotechnology (ed. by T.W. Flegel), pp. 273-276. National Center for Genetic Engineering and Biotechnology, Bangkok.

Lo C.F., Leu J.H., Ho C.H., Chen C.H., Peng S.E., Chen Y.T., Chou C.M., Yeh P.Y., Huang C.J., Chou H.Y., Wang C.H. \& Kou G.H. (1996) Detection of baculovirus associated with white spot syndrome (WSBV) in penaeid shrimps using polymerase chain reaction. Diseases of Aquatic Organisms 25, 133-141.

Nadala E.C.B. \& Loh P.C. (2000) Dot-blot nitrocellulose enzyme immunoassays for the detection of white-spot virus and yellow-head virus of penaeid shrimp. Journal of Virological Methods 84, 175-179.

Nadala E.C.B., Tapay L.M., Cao S. \& Loh P.C. (1997) Detection of yellowhead virus and Chinese baculovirus in penaeid shrimp by the Western blot technique. Journal of Virological Methods 69, 39-44.

Reed L.J. \& Muench H. (1938) A simple method of estimating fifty percent endpoints. American Journal of Hygiene 27, 493-497.

Samuel D., Megson B., Strang M. \& Appelton H. (2000) A microtitre plate method for isolation and typing of poliovirus using a Blue-Cell ELISA. Journal of Virological Methods 90, 125-133.

Shih H.H., Wang C.S., Tan L.F. \& Chen S.N. (2001) Characterization and application of monoclonal antibodies against white spot syndrome virus. Journal of Fish Diseases 24, 143-150.

Tang K.F.J. \& Lightner D.V. (2000) Quantification of white spot syndrome virus DNA through a competitive polymerase chain reaction. Aquaculture 189, 11-21.

Tapay L.M., Lu Y., Gose R.B., Nadala E.C.B., Brock J.A. \& Loh P.C. (1997) Development of an in vitro quantal assay in primary cell cultures for a non-occluded baculo-like virus of penaeid shrimp. Journal of Virological Methods 64, 37-41.

Wang C.S., Tsai Y.J., Kou G.H. \& Chen S.N. (1997) Detection of white spot disease virus infection in wild-caught greasy back shrimp, Metapenaeus ensis (de Haan) in Taiwan. Fish Pathology 32, 35-41.

Wang C.S., Tsai Y.J. \& Chen S.N. (1998) Detection of white spot disease virus (WSDV) infection in shrimp using in situ hybridization. Journal of Invertebrate Pathology 72, 170-173.

Wang C.H., Yang H.N., Tang C.Y., Liu C.H., Kou G.H. \& Lo C.F. (2000) Ultrastructure of white spot syndrome virus development in primary lymphoid organ cell cultures. Diseases of Aquatic Organisms 41, 91-104.

Received: 3 September 2001

Accepted: 14 November 2001 